Polish Journal of Microbiology

2011, Vol. 60, No 2, 125-131

ORGINAL PAPER

\title{
Comparison of the Nucleotide Sequences of Wheat Dwarf Virus (WDV) isolates from Hungary and Ukraine
}

\author{
ISTVÁN TÓBIÁS ${ }^{1 *}$, OLEKSIY SHEVCHENKO ${ }^{2}$, BALÁZS KISS ${ }^{1}$, ANDRIY BYSOV², HALINA SNIHUR², \\ VALERY POLISCHUK ${ }^{2}$, KATALIN SALÁNKI ${ }^{3}$ and LÁSZLÓ PALKOVICS ${ }^{4}$
}

${ }^{1}$ Plant Protection Institute, Hungarian Academy of Sciences, Budapest, Hungary

${ }^{2}$ Taras Shevchenko' Kyiv National University, Kyiv, Ukraine

${ }^{3}$ Agricultural Biotechnology Centre, Gödölló, Hungary

${ }^{4}$ Corvinus University of Budapest, Department of Plant Pathology, Budapest, Hungary

Received 10 October 2010, revised) 21 January 2011, accepted 5 February 2011

Abstract

Wheat dwarf virus (WDV) is the most ubiquitous virus in cereals causing huge losses in both Hungary and Ukraine. The presence of barleyand wheat-adapted strains has been confirmed, suggesting that the barley strain is restricted to barley, while the wheat strain is present in both wheat and barley plants. Five WDV isolates from wheat plants sampled in Hungary and Ukraine were sequenced and compared with known WDV isolates from GenBank. Four WDV isolates belonged to the wheat strain. Our results indicate that WDV-Odessa is an isolate of special interest since it has originated from wheat, but belongs to the barley-adapted strain, providing novel data on WDV biology and raising issues of pathogen epidemiology.

Ke y words: Wheat dwarf virus (WDV), nucleotide sequence of WDV

\section{Introduction}

During the last decade Wheat dwarf virus (WDV) has been the most frequently isolated and most ubiquitous cereal-infecting virus in Hungary and it has now become a serious problem also in the Ukraine (Mesterházy et al., 2002, Szunics et al., 2003, Snihur et al., 2007). WDV is a frequent causal agent of dwarfing, mottling, yellowing or reddening in cereals and suppressed heading and root growth in infected plants can drastically reduce yield. WDV was first described by Vacke (1961) in the former Czechoslovakia and subsequently found in Sweden (Lindsten et al., 1970), Bulgaria (Stephanov and Dimov, 1981), Hungary (Bisztray et al., 1989), France (Lindsten and Lindsten, 1993), Germany (Huth, 2000), Poland (Jezewska, 2001), Finland (Lemmetty and Huusela-Veistola, 2005), Romania (Jilaveanu and Vacke, 1995), Spain (Achon et al., 2006), Tunisia (Najar et al., 2000), Turkey (Köklü et al., 2007), Zambia (Kapooria and Ndunguru, 2004), Ukraine (for the first time approximately in 1975 (Razvyazkina 1975), then in 2007 (Snihur et al., 2007) and China (Xie et al., 2007). WDV is transmitted by the European grass-feeding leafhopper Psammotettix alienus (Vacke, 1961) in a circulative, non-propagative manner (Lindsten and Vacke, 1991), therefore the occurrence of diseased plants in the field depends on the presence of the vector. During the crop screening for WDV conducted in 2009-2010, the unique virus vector, Psammotettix alienus, has been found in abundance in Ukrainian agroecosystems, providing indirect proof of widespread presence of WDV in the Ukraine.

WDV belongs to the genus Mastrevirus (family Geminiviridae) infecting monocotyledonous plants. Mastreviruses have a monopartite single-stranded genome of circular DNA and the genome encodes four different proteins: movement protein (MP) and coat protein $(\mathrm{CP})$ on the viral sense strand, and two replication-associated proteins (Rep and RepA) on the complementary strand (Gutierrez, 1999). The presence of an intron in the Rep gene makes it possible for WDV to produce two different forms of the replication protein. The non-coding long intergenic region (LIR) and short intergenic region (SIR) contain sequence elements necessary for viral replication and transcription. The LIR comprises the origin of rolling circle replication of the virus (Heyraud et al., 1993). The SIR contains polyadenylation signals and a region to which a short complementary primer for the second strand synthesis binds (Kammann et al., 1991).

* Corresponding author: I. Tóbiás, Plant Protection Institute, Hungarian Academy of Sciences; H-1525 Budapest, P.O.Box 102, Hungary; fax: +36 13918655 ; e-mail: tobias@julia-nki.hu 
Two different forms of WDV exist: a wheat-adapted form (WDV wheat strain) and a barley-adapted form (WDV barley strain) (Lindsten and Vacke, 1991; Bendahmane etal., 1995, Kvarnheden et al., 2002). Both strains infect a number of plant species in the family Poaceae (Lindsten and Vacke, 1991). There are, however, contradictory reports on whether the wheat strain can infect barley, and whether the barley strain can infect wheat. Lindsten and Vacke (1991) and Tóbiás et al. (2009) observed no transmission of the barley strain to wheat, whereas the wheat strain was transmissible to barley. Similar conclusion was made by Kundu et al. (2009), who found that the barley strain is restricted to the barley host, while the wheat strain is present in both wheat and barley plants. Mechner et al. (2003) detected both WDV strains in barley plants in the fields, using strain specific primers. Commandeur and Huth (1999) and Schubert et al. (2007) found that the barley strain can infect wheat only under laboratory conditions.

The genomes of the barley and wheat strains of WDV share an average of $85 \%$ identity. The isolates within the wheat strain show a high degree of homo$\operatorname{logy}(>98 \%$ identity), whereas the isolates of the barley strain are more variable ( $>94 \%$ identity). As the demarcation criterion for mastrevirus species has been set to $75 \%$ nucleotide sequence identity by the International Committee for Taxonomy of Viruses (Fauquet et al., 2008), both strains are currently considered to belong to the same species. Schubert et al. (2007) recently proposed two new mastrevirus species Barley dwarf virus
(BDV) and Oat dwarf virus (ODV) based on DNA sequence differences. ODV was accepted as a new tentative mastrevirus species sharing $70 \%$ genome-wide nucleotide sequence identity with the wheat and barley strains of WDV (Fauquet et al., 2008).

The aim of the present study was the molecular characterisation of WDV isolates from Hungary and Ukraine and their comparison with the available sequences of WDV.

\section{Experimental}

\section{Materials and Methods}

Virus isolates. Symptoms of viral infection were found during spring observations carried out in wheat crops in Martonvasar (Middle Hungary), Pula (Southern Hungary) and Mironivka (Middle Ukraine). Plants displaying yellowing of leaves or dwarfing were placed in an insect-proof greenhouse and were tested for WDV by ELISA using a WDV kit (Bio-Rad). The collected WDV-infected plants were replanted into clay pots and placed in an insect-proof isolation net. For virus transmission, thirty individuals of virus-free Psammotettix alienus Dahlb. were placed underneath each net. One week later the leafhoppers were transferred to young seedlings of wheat being in two leaves stage. Six weeks later the plants were tested again for WDV by ELISA. Three isolates, WDV-HU-2Marton (collected in 2008 from Martonvasar), WDV-HU-Pula

Table I

Primers used for sequencing

\begin{tabular}{|l|ll|l|}
\hline \multicolumn{1}{|c|}{ Name } & \multicolumn{2}{|c|}{ Genome position ${ }^{1}$} & \multicolumn{1}{|c|}{ Sequence (5'-3') } \\
\hline WDV-Barley forw & $468-488$ & (B) & ATCCCGGGTCCTCCGACTAC \\
\hline WDV-Barley rev & $478-458$ & $(\mathrm{~B})$ & GACCCGGGATCGTAAGGGGC \\
\hline WDV-Barley 540 & $555-531$ & $(\mathrm{~B})$ & TAAGCCAAACAAACAACTCCTACGG \\
\hline WDV-P1 & $611-631$ & $(\mathrm{~B})$ & GACCGAGGAAATTGGTTACGG \\
\hline WDV-5 & $1045-1067$ & $(\mathrm{~B})$ & CCACTGACATCTTTACGATGCC \\
\hline WDV-Barley 1200 & $1200-1225$ & $(\mathrm{~B})$ & AACTACGTAGTGGGGAAGAATATCG \\
\hline WDV-Barley 1900 & $1895-1917$ & $(\mathrm{~B})$ & CATAGGTCGTGAAATTCAACTAG \\
\hline WDV-Barley 2110 & $2094-2122$ & $(\mathrm{~B})$ & TTCGAGGCTTACGGAGTAGAGATGTTCAT \\
\hline WDV-Wheat P1 & $475-494$ & $(\mathrm{~W})$ & GACCGAGGAAATTGGTTACGG \\
\hline WDV-Wheat 483 & $506-485$ & $(\mathrm{~W})$ & GCTTATACACAGCCCCCTTCC \\
\hline WDV-Wheat 5 & $809-831$ & $(\mathrm{~W})$ & CCACTGACATCTTTACGATGCC \\
\hline WDV-Wheat 1076 & $1069-1087$ & $(\mathrm{~W})$ & TAAGAAAGGAGCACTGTATC \\
\hline WDV-Wheat 1410 & $1428-1406$ & $(\mathrm{~W})$ & GCGAGTCATTCATCAACTACTCG \\
\hline WDV-Wheat 1850 & $1850-1482$ & $(\mathrm{~W})$ & CCACTCCTGCGGATCAAGC \\
\hline WDV-Wheat forw & $2305-2326$ & $(\mathrm{~W})$ & ACGAAGCTTGTTCTGCACGAGA \\
\hline WDV-Wheat rev & $2316-2295$ & $(\mathrm{~W})$ & AACAAGCTTCGTGCTTCCATC \\
\hline WDV-Wheat 2521 & $2521-2542$ & $(\mathrm{~W})$ & CAGAAGTCCGGCAGGTCCTTA \\
\hline
\end{tabular}

${ }^{1}$ With reference to WDV-Heves (FM999833) - B and WDV-2 Marton (FN806785) - W. 
Table II

Abbreviation, accession number and origin of Wheat dwarf virus isolates used in this study

\begin{tabular}{|c|c|c|}
\hline Abbreviation & $\begin{array}{c}\text { Accession } \\
\text { number }\end{array}$ & $\begin{array}{c}\text { Country } \\
\text { of collection }\end{array}$ \\
\hline WDV-HU-B & AM040732 & Hungary \\
\hline WDV-HU-F & AM040733 & Hungary \\
\hline WDV-HU-H07 & FM210034 & Hungary \\
\hline WDV-HU-Heves & FM999833 & Hungary \\
\hline WDV-HU-Dunakiliti & FM999832 & Hungary \\
\hline WDV-HU-Martonbar & AM747816 & Hungary \\
\hline WDV-HU-2Marton & FN806785 & Hungary \\
\hline WDV-HU-Pula & FN806786 & Hungary \\
\hline WDV-Uk-g & FN806783 & Ukraine \\
\hline WDV-Uk-Miron & FN806784 & Ukraine \\
\hline WDV-Uk-Odessa & FN806787 & Ukraine \\
\hline WDV-BU-Bg17 & AM989927 & Bulgaria \\
\hline WDV-Swe-Enk1 & AJ311031 & Sweden \\
\hline WDV-Swe-Enk2 & AM491490 & Sweden \\
\hline WDV-Swe-SE & X02869 & Sweden \\
\hline WDV-Chi-hbsjz061 & EF536870 & China \\
\hline WDV-Chi-ynkm062 & EF536881 & China \\
\hline WDV-Chi-sxyl052 & EF536878 & China \\
\hline WDV-Chi-gsgg050 & EF5368591 & China \\
\hline WDV-Chi-sxyl051 & EF536877 & China \\
\hline WDV-Ge-SxA22 & AM296022 & Germany \\
\hline WDV-Ge-SxA23 & AM296023 & Germany \\
\hline WDV-Ge-SxA24 & AM296024 & Germany \\
\hline WDV-Ge-SxA25 & AM296025 & Germany \\
\hline WDV-Ge-SCBB21 & AM296021 & Germany \\
\hline WDV-Ge-BaW1 & AM411651 & Germany \\
\hline WDV-Ge-BaW2 & AM411652 & Germany \\
\hline WDV-Ge-McP20 & AM296020 & Germany \\
\hline WDV-Ge-Sx18 & AM296018 & Germany \\
\hline WDV-Cz-6217 & FJ546189 & Czech Republic \\
\hline WDV-Cz-6239 & FJ546190 & Czech Republic \\
\hline WDV-Cz-W & FJ546188 & Czech Republic \\
\hline WDV-Cz-1841 & FJ546191 & Czech Republic \\
\hline WDV-Cz-19 & AM296019 & Czech Republic \\
\hline WDV-Cz-11105 & FJ546180 & Czech Republic \\
\hline WDV-Cz-8100 & FJ546179 & Czech Republic \\
\hline WDV-Cz-11229 & FJ546181 & Czech Republic \\
\hline WDV-Cz-6482 & FJ546178 & Czech Republic \\
\hline WDV-Cz-B & FJ546193 & Czech Republic \\
\hline WDV-Tr-bar & AJ783960 & Turkey \\
\hline
\end{tabular}

WDV isolates sequenced in this study are indicated in bold type.

(collected in 2007 from Pula) and WDV-Uk-Miron (collected in 2009 from Mironivka and maintained in our greenhouse by subsequent transmission) were selected for further studies. Ten wheat samples from the Odessa region (South Ukraine) and one from Glevakha (Central North Ukraine) were initially tested by PCR with WDV specific primers. Two samples (WDV-Uk-Odessa and WDV-Uk-g collected from Odessa and Glevakha, respectively) were selected for molecular characterization.

Isolation of virus DNA, cloning and sequence analysis of the WDV isolates. DNA extraction was done according to Shepherd et al. (2008) with a slight modification (fresh leaf material was used instead of dry leaves). The samples were then stored at $-20^{\circ} \mathrm{C}$ or used directly as a template for rolling circle amplification (RCA) of the WDV genome (Haible et al., 2006). One microliter of the final Extract-n-Amp DNA solution was mixed with $4 \mu \mathrm{l}$ of Templi $\mathrm{Phi}^{\mathrm{TM}}$ sample buffer (TempliPhi ${ }^{\mathrm{TM}}$, Amersham Biosciences), heated for $2 \mathrm{~min}$ at $94^{\circ} \mathrm{C}$, and then brought to room temperature. Five $\mu \mathrm{l}$ of reaction buffer and $0.2 \mu \mathrm{l}$ of enzyme mix were added to the cooled mixture and the Templi Phi ${ }^{\mathrm{TM}}$ extension reaction was run at $30^{\circ} \mathrm{C}$ for $18-20 \mathrm{~h}$. WDV genome concatemers (multiple copies of unit-length virus genomes covalently linked end-to-end) generated during Phi29 DNA polymerase amplification were digested with HindIII (wheat strain) or SmaI (barley strain) to release unit-length genomes. After digestion genomic DNA was separated in $1 \%$ agarose gel and extracted with a DNA purification kit (Fermentas DNA Extraction Kit). The WDV genome was inserted into a HindIII or SmaI digested pBSK+ plasmid (Stratagene). The recombinant plasmids were transformed into Escherichia coli DH5a (Sambrook et al., 1989).

Clones containing inserts with the expected size of $2.7 \mathrm{~kb}$ were sequenced with the DyeDeoxyTerminator Kit (Applied Biosystems) using reverse, universal $(-20)$ and internal primers (Table I). Sequence analysis was performed using University of Wisconsin Genetics Computer Groups (GCG) sequence analysis software package version 9.1.

In order to determine the phylogenetic relationships between different WDV isolates complete genomes were analysed (Table II). Sequence alignment, tree formation, and bootstrap analysis were done with the help of the software Clustal X 1.83 .

\section{Results and Discussion}

This work has been focused on the screening of Hungarian and Ukrainian cereal ecosystems for the presence of Wheat dwarf virus and its unique vector, P. alienus. The outcomes of the 2-year monitoring clearly demonstrated significant spread of the virus in Ukraine and confirmed the positive tendency in its spread compared to previous years of observations. In addition, for the first time a virus vector has been 
Table III

Sequence identity of complete genomes of the WDV isolates characterized in our laboratory

\begin{tabular}{|l|c|c|c|c|c|c|c|c|c|c|}
\hline \multicolumn{1}{|c|}{ WDV } & B & F & 2Marton & H07 & Heves & Dunakiliti & Bg17 & Mironivka & .g & Odessa \\
\hline Pula & 99.5 & 99.5 & 99.2 & 85.3 & 85.5 & 85.3 & 85.4 & 98.7 & 99.5 & 85.5 \\
\hline B & & 99.6 & 99.4 & 85.1 & 85.3 & 85.1 & 85.2 & 98.7 & 99.6 & 85.3 \\
\hline F & & & 99.3 & 85.2 & 85.4 & 85.2 & 85.3 & 98.7 & 99.4 & 85.3 \\
\hline 2Marton & & & & 85.3 & 85.2 & 85 & 85.1 & 98.4 & 99.3 & 85.2 \\
\hline H07 & & & & & 99.3 & 99 & 96.3 & 84.9 & 84.9 & 96.5 \\
\hline Heves & & & & & & 99.4 & 96.6 & 85.1 & 85.1 & 96.8 \\
\hline Dunakiliti & & & & & & & 96.6 & 84.9 & 84.9 & 96.9 \\
\hline Bg17 & & & & & & & & 85.1 & 85 & 99.3 \\
\hline Mironivka & & & & & & & & & 98.7 & 85.2 \\
\hline g & & & & & & & & & & 85.1 \\
\hline
\end{tabular}

Abbrevations and accession numbers: WDV-HU-B: AM040732, WDV-HU-F: AM040733, WDV-HU-H07: FM210034, WDV-HU-Heves: FM999833, WDV-HU-Dunakiliti: FM999832, WDV-BU-Bg17: AM989927, WDV-Uk-g: FN806783, WDV-Uk-Miron: FN806784, WDV-HU-2Marton: FN806785, WDV-HU-Pula: FN806786 and WDV-Uk-Odessa: FN806787

shown to be common to Ukrainian fields since it has been detected in virtually every region of the country where the virus was identified.

Depending on the place of origin, the degree of WDV infection of collected wheat plants was 20-70\% as confirmed by ELISA tests and PCR. In laboratory, the virus was transmitted by P. alienus in insect-proof isolation net and maintained on oat or wheat plants. Nucleic acids were isolated from plants infected with WDV-HU-2Marton, WDV-HU-Pula, WDV-Uk-g and WDV-Uk-Odessa, WDV-Uk-g and WDV-Uk-Miron and used for subsequent molecular and phylogenetic characterization.

The Extraction-n-Amp DNA extraction method was very rapid and simple in order to isolate intact viral DNA. WDV genome amplification via the RCA method generates large DNA concameters, from which unit-length genome were subsequently cleaved with HindIII or SmaI enzymes. The size of the full length genome obtained for WDV-HU-2Marton and WDV-HU-Pula constituted 2750 nucleotides, while the genomes of WDV-Uk-g and WDV-Uk-Miron were 2749-nucleotide-long, and the WDV-Uk-Odessa genome was exactly 2734 nucleotides in length. The very special property of this latter isolate is hat it has originated from the winter wheat variety Selyanka. To our knowledge, this is the first report of the barley strain of WDV isolated from naturally infected wheat plants. The genomes of these characterized isolates contained all four expressed mastrevirus ORFs (MP, CP, Rep, RepA), and the intergenic regions LIR and SIR.

The nucleotide sequences were deposited in GenBank as WDV-Uk-g: FN806783, WDV-Uk-Miron: FN806784, WDV-HU-2Marton: FN806785, WDV-HUPula: FN806786 and WDV-Uk-Odessa: FN806787, and were further compared to previously characterized WDV isolates (Tobias et al., 2006, 2009, 2010) (Table III).

The analysis of the full genome sequences revealed high levels of identity among wheat strains and higher level of diversity among barley strains. The sequences' identities between isolates of the wheat strain of different geographical origins were very similar $(>98.7 \%$ identity). For the movement protein (MP) and coat protein $(\mathrm{CP})$, we observed high sequence identity $(>98.8 \%)$ at the predicted amino acid level, in some cases MPs (Hungarian and Swedish isolates) and CPs (Hungarian isolates originating from different parts of the country) were identical. For the short (SIR) and large intergenic region (LIR), we observed a higher variability ( $97 \%$ and $96.6 \%$ identity, respectively) (data not shown). Regarding the diversity of the WDV isolates of the barley strain, we observed a relatively high variability (96.3-99.4\%). Interestingly, however, the MP and $\mathrm{CP}$ also revealed a high level of amino acid sequence identity among barley strain isolates originating from different geographical regions (98.5-100\%). Similar to wheat strain isolates, barley strain isolates showed greater variability also in the LIR and SIR.

Molecular characterization of Ukrainian and Hungarian WDV isolates was followed by phylogenetic analysis in order to compare their relationships with previously characterized wheat and barley isolates available from the GenBank database (Fig. 1). The phylogenetic analysis of WDV isolates showed that they were clearly distinguishable, both barley and wheat strains formed two clades. Isolates from Hungary, Germany, Czech Republic, Ukraine and Sweden clustered in clade 1. Interestingly, both Ukrainian isolates WDVUk-g and WDV-Uk-Miron showed closer relationship to WDV-HU-Pula and WDV-Swe-Enk2 isolates, respectively, than to each other. This is surprising as 


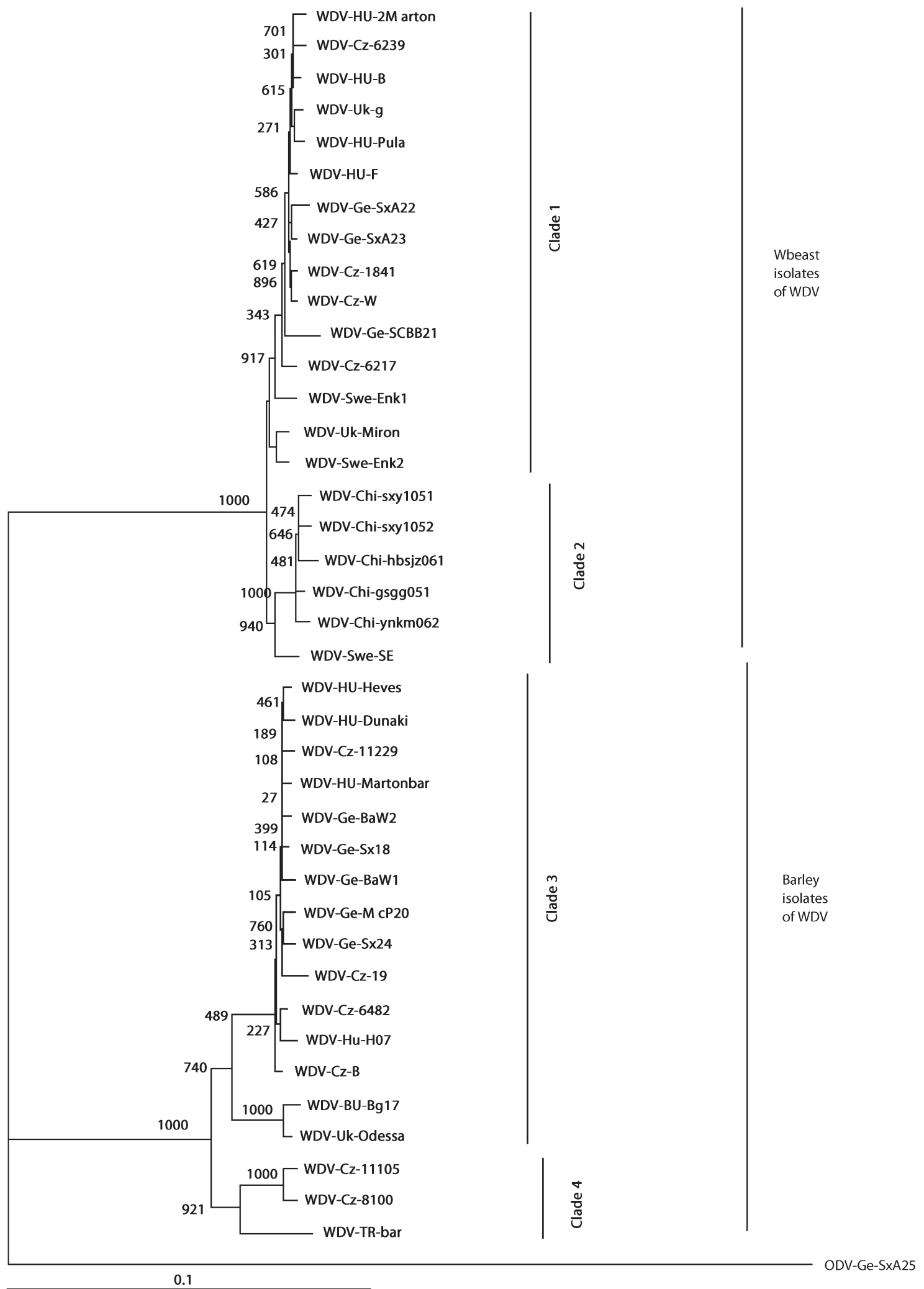

Fig. 1. Phylogenetic tree constructed by the UPGMA method for complete genome sequences of Wheat dwarf virus isolates. (Bootstrap values are indicated) The isolate ODV-Ge-SxA25 was used as the outgroup with a $c a$. 70\% genome-wide nucleotide sequence identity with barley and wheat strain isolates of WDV. 
according to the available literature data phylogenetic relationships of WDV isolates normally show high degree of dependence on the geographical origin of the virus (Köklü et al., 2007). However, both WDV-Uk-g and WDV-Uk-Miron isolates came from the same geographical region of the Ukraine (Kiev region, central north of the Ukraine) and the sites of sampling were situated just approximately $100 \mathrm{~km}$ apart from each other. Apparently, other issues (such as vector occurrence and behaviour, plant cultivars cultivated at a given territory, agricultural techniques and, primarily, the initial virus source in the country) should be considered as well when evaluating spread and evolutionary divergence of WDV.

Clade 2 could be divided into two subgroups, one with wheat isolates from China and the other containing only the WDV-Swe-SE isolate from Sweden.

As for the isolates of barley strain of WDV, clade 3 could be divided into two subgroups, one with a divergent pool of isolates from Hungary, Germany and Czech Republic. The other subgroup comprised Ukrainian and Bulgarian isolates of WDV-BU-Bg17 and WDVUk-Odessa. In Clade 4, WDV-TR-bar isolate formed one subgroup and WDV-Cz-11105 and WDV-Cz-8100 formed the other one. These observations are in a good agreement with previous results (Schubert et al., 2007, and Kundu et al., 2009).

In conclusion, the results presented in this work have shown that Hungarian and Ukrainian isolates of WDV were divided into two distinct groups of wheat and barley strains. WDV-Uk-Odessa is the first barley strain isolate originating from wheat infected under natural conditions. At this point it should be mentioned that we have managed to identify the barley strain of WDV in a single wheat plant only once during the intensive two-year strain-specific PCR-based screening of WDV isolates in naturally grown cereal crops in Hungary and Ukraine. Hence the proven fact of WDV barley strain transmission to wheat plants by P. alienus is obviously an uncommon and rare event. Seemingly it may happen under natural conditions but only occasionally and possibly when virus concentrations in host plants are high enough to allow host range extension by overcoming typical limitations on virusplant relationships.

In our opinion, the issue of WDV transmission by its vector needs further characterization especially by employing molecular approaches to identify virus genes and/or gene products (and preferably their vector counterparts) responsible for the transmission of the virus and its efficiency.

\footnotetext{
Acknowledgements

This research was supported by a Hungarian Scientific Research Found (OTKA 61644 and 68589). TI, KB, PL, SO, SH and BA were
} supported by TéT (UA-14/8).

\section{Literature}

Achon M.A., L. Serrano, L. Ratti and C. Rubies-Autonell. 2006. First detection of Wheat dwarf virus in barley in Spain associated with an outbreak of barley yellow dwarf. Plant Dis. 90: 970. Bendahmane M., H-J. Schalk and B. Gronenborn. 1995. Identification and characterization of wheat dwarf virus from France using a rapid method for geminivirus DNA preparation. Phytopathology 85: 1449-1455.

Bisztray Gy., R. Gáborjányi and J. Vacke. 1989. Isolation and characterisation of wheat dwarf virus found for the first time in Hungary. J. Plant. Dis. Protect. 96: 449-454.

Commandeur U. and W. Huth. 1999. Differentiation of strains of wheat dwarf virus in infected wheat and barley plants by means of polymerase chain reaction. J. Plant. Dis. Protect. 106: 550-552.

Fauquet C.M., R.W. Briddon, J.K. Brown, E. Moriones, J. Stanley, M. Zerbini and X. Zhou. 2008. Geminivirus strain demarcation and nomenclature. Arch. Virol. 153: 783-821.

Gutierrez C. 1999. Geminivirus DNA replication. Cell. Mol. Life Sci. 56: 313-329.

Haible D., S. Kober and H. Jeske. 2006. Rolling circle amplification revolutionizes diagnosis and genomics of geminiviruses. J. Virol. Meth. 135: 9-16.

Heyraud F., V. Matzeit, M. Kammann, S. Schaefer, J. Schell and B. Gronenborn. 1993. Identification of the initiation sequence for viral-strand DNA synthesis of wheat dwarf virus. EMBO J. 12: 4445-4452.

Huth W. 2000. Viruses of Gramineae in Germany - a short overview. J. Plant. Dis. Protect. 107: 406-414.

Jezewska J. 2001. First report of Wheat dwarf virus occurring in Poland. Phytopath Polonica 21: 93-100.

Jilaveanu A. and J. Vacke. 1995. Isolation and identification of wheat dwarf virus (WDV) in Romania. Probleme de Protectia Plantelor 23: 51-62.

Kammann M., H.J. Schalk, V. Matzeit, S. Schaefer, J. Schell and B. Gronenborn. 1991. DNA replication of wheat dwarf virus, a geminivirus, requires two cis-acting signals. Virology 184: 786-790. Kapooria R.G. and J. Ndunguru. 2004. Occurrence of viruses in irrigated wheat in Zambia. EPPO/OEPP Bulletin 34: 413-419.

Köklï G., J.N.E. Ramsell and A. Kvarnheden. 2007. The complete genome sequence for a Turkish isolate of Wheat dwarf virus (WDV) from barley confirms the presence of two distinct WDV strains. Virus Genes 34: 359-366.

Kundu J.K., S. Gadiou and G. Cervená. 2009. Discrimination and genetic diversity of Wheat dwarf virus in Czech Republic. Virus Genes 38: 468-474.

Kvarnheden A., M. Lindblad, K. Lindsten and J.P.T. Valkonen. 2002. Genetic diversity of Wheat dwarf virus. Arch. Virol. 147: 205-216. Lemmetty A. and E. Huusela-Veistola. 2005. First report of Wheat dwarf virus in winter wheat in Finland. Plant Dis. 89: 912.

Lindsten K. and B. Lindsten. 1993. Occurrence and transmission of Wheat dwarf virus (WDV) in France. In: Proceedings of Third International Conference on Pest in Agriculture 7-9 December 1993, Montpellier, France, pp. 41-48.

Lindsten K. and J. Vacke. 1991. A possible barley adapted strain of Wheat dwarf virus (WDV). Acta Phytopath. Entomol. Hung. 26: 175-180.

Lindsten K, J. Vacke and B. Gerhardson. 1970. A preliminary report on three cereal virus diseases new to Sweden spread by Macrosteles and Psammotettix leafhoppers. Nat. Swedish Inst. Plant. Protec. Cent. 14: 285-297.

Mechner S., B. Manurung, M. Grüntzig, A. Habekuss, W. Witsack and E. Fuchs. 2003. Investigations into the ecology of the Wheat dwarf virus (WDV) in Saxony-Anhalt, Germany. J. Plant Dis. Protect. 110: 313-323. 
Mesterházy Á., R. Gáborjányi, M. Papp and P. Fónad. 2002. Multiple virus infection of wheat in South Hungary. Cer. Res. Com. 30: 329-334.

Najar A., K.M. Makkouk, H. Boudhir, S.G. Kumari, R. Zarouk, R. Bessai and F.B. Othman. 2000. Viral diseases of cultivated legume and cereal crops in Tunisia. Phyt. Medit. 39: 423-432. Razvyazkina G.M. 1975. Virus Diseases of Cereals - Novosibirsk, 1975 - 292 p. (in Russian)

Sambrook J., E.F. Fritsch and T. Maniatis. 1989. Molecular Cloning. A Laboratory Manual. $2^{\text {nd }}$ ed. Cold Spring Harbor Laboratory, Cold Spring Harbor, New York.

Schubert J., A. Habekuss, K. Kazmaier and H. Jeske. 2007. Surveying cereal-infecting geminiviruses in Germany - Diagnostics and direct sequencing using rolling circle amplification. Virus Research 127: 61-70.

Shepherd D., PD Martin, P. Lefeuvre, A. Monjane, B. Owor, E.P. Rybicki and A. Varsani. 2008. A protocol for the rapid isolation of full geminivirus genomes from dried plant tissue. J. Virol. Meth. 149: 97-102.

Snihur H., V. Polischuk and U. Kastirr. 2007. Dissemination of viruses of cereal crops in agrocoenosises of Ukraine. // $10^{\text {th }}$ International Plant Virus Epidemiology Symposium. 15-20 October 2007, ICRISAT, Hyderabad, India. P. 107.
Stephanov J. and A. Dimov. 1981. Bolestta vdjudjavanje po spenittsata Bolgaria. Rasteniev Nauki 18: 124-128 (in Bulgarian with English summary).

Szunics L., E. Pocsai, G. Vida, O. Veisz, L. Láng and Z. Bedő. 2003. Kalászos gabonák vírusok okozta betegségei 2002-ben. Növénytermelés 52: 33-39 (in Hungarian with English summary).

Tóbiás I., B. Kiss and L. Palkovics. 2006. The nucleotide sequence of two Hungarian isolates of Wheat dwarf virus. Acta Phytopath. et Entomol. Hung. 41: 47-52.

Tóbiás I., B. Kiss, É. Pájtli, G. Tholt and K. Salánki. 2008. Molecular characterization and transmission experiments with barley strain of Wheat dwarf virus. Növényvédelem 44(11), 545-552. (in Hungarian with English summary)

Tóbiás I., B. Kiss, N. Bakardjieva and L. Palkovics. 2009. The nucleotide sequence of barley strain of Wheat dwarf virus isolated in Bulgaria. Cer. Res. Com. 37: 237-242.

Tóbiás I., B. Kiss, K. Salánki and L. Palkovics. 2010. The nucleotide sequence of barley strain of Wheat dwarf virus isolated in Hungary. Cereal Research Communication 38: 67-74.

Vacke J. 1961. Wheat dwarf virus. Biol. Plant. 3: 228-233.

Xie J., X.Wang, Y. Liu, Y. Peng and G. Zyhou. 2007. First report of the occurrence of Wheat dwarf virus in wheat in China. Plant Dis. 91: 111. 